\title{
Kebijakan Bantuan Pangan Non Tunai Dalam Perspektif Filsafat Hukum Murni
}

\author{
Gunawan $^{1}$, Haris Widiasmoro ${ }^{2}$, dan Layla Izza Rufaida ${ }^{3}$ \\ 1,2,3 Magister Hukum Tindak Pidana Ekonomi, Universitas Sebelas Maret \\ Corresponding author. Email : gnw.wibisono.1973@gmail.com
}

Naskah diterima: 05-01-2021 revisi: 04-09-2021; disetujui: 18-05-2021

DOI: https://doi.org/10.46257/jrh.v25i1.189

\begin{abstract}
Abstrak
Bantuan pangan nontunai bersendikan efisiensi berkeadilan dan ekonomi inklusif. Norma hukum efisiensi berkeadilan mensyaratkan pemerataan sebesar-besarnya bagi rakyat Indonesia. Permasalahan dalam penelitian ini adalah bagaimanakah filosofis efisiensi berkeadilan pada program bantuan pangan nontunai. Tujuan penelitian yaitu untuk menganalisis filosofi efisiensi berkeadilan melalui filsafat hukum yang diterangkan oleh Hans Kelsen. Metode penelitian yang digunakan adalah yuridis normatif. Hasil yang ditemukan pada kajian ini ialah gagasan Bantuan Pangan Non Tunai (BPNT) awalnya bersendikan distribusi pangan berbasis efisiensi (asasnya) dan memberlakukan redistribusi keuangan inklusif. Artinya dalam ranah ide dasar BPNT masih di dalam program yang sewajarnya, namun di salah satu lokasi, implementasi program ini bermasalah dalam mewujudkan keadilan masyarakat. Pendulum efisiensi dominan ke arah ekonomi penguasa kapital, sehubungan dengan fakta hukum adanya monopoli jalur pasokan ke E-Warong. Berkeadilan yang berbasis pada kemakmuran sebesar-besarnya bagi masyarakat (utilitarianisme) masih menjadi distopia (jauh dari ideal). Dapat disimpulkan bahwa perspektif filsafat hukum Hans Kelsen tidak sesuai dengan implementasi program BPNT pada aspek operasional keadilan ditingkat pelaksanaannya. Sudah saatnya merubah pola distribusi pasokan bahan pangan dengan kebijakan bantuan langsung tunai.
\end{abstract}

Kata kunci: bantuan pangan non-tunai, perspektif filsafat hukum.

\section{Non-Cash Food Assistance Policy In The Pure Theory of Law Philosophy Perspective}

\begin{abstract}
Non-cash food aid is based on equitable efficiency and an inclusive economy. The legal norms of equitable efficiency require as much equity as possible for the Indonesian people. The problem in this research is what is the philosophy of fair efficiency in the non-cash food aid program? The purpose of this article is to analyze the philosophy of equitable efficiency through the philosophy of law explained by Hans Kelsen. The research method used is normative juridical. The result found in this study is that the idea of Non-Cash Food Assistance (BPNT) was originally based on efficiency-based food distribution (in principle) and imposed inclusive financial redistribution. This means that in the realm of basic ideas, BPNT is still in a proper program, but in one location, the implementation of this
\end{abstract}




\begin{abstract}
program has problems in realizing community justice. The dominant efficiency pendulum is towards the economy of the capital ruler, due to the fact that there is a monopoly supply line to E-Warong. Justice based on the greatest possible prosperity for society (utilitarianism) is still a dystopia (far from ideal). It can be concluded that the perspective of Hans Kelsen's legal philosophy is not in accordance with the implementation of the BPNT program in the operational aspects of justice at the implementation level. It is time to change the distribution pattern of food supply with the policy of direct cash transfers.
\end{abstract}

Keywords: non-cash food aid, legal philosophy perspective.

\title{
I. Pendahuluan
}

Program kebijakan pemerintah diperlukan kajian atau naskah akademis dalam mengawali konsep kebijakan. Tujuannya agar program terlaksana sebagaimana awal pembentukan. Niat baik saja tidak mencukupi dalam mempertanggungjawabkan keuangan Negara dalam setiap program kebijakan. Lebih dari itu juga menyangkut hajat hidup orang banyak, sehingga perlu ketepatan program agar terwujud ikhtiar dalam memajukan kesejahteraan umum sebagaimana diamanatkan dalam pembukaan UUD 1945.

Bantuan Pangan Non Tunai (BPNT), adalah bantuan dalam kebijakan sosial berupa pangan, yang distribusi penyalurannya berwujud non tunai (e-money) dari pemerintah tertuju pada Keluarga Penerima Manfaat (KPM). Pemberian dilakukan tiap bulan, selanjutnya dipergunakan oleh KPM guna membeli bahan pangan di Elektronik Warong. Sementara itu, wilayah yang termasuk berakses terbatas, tata cara penerapan BPNT diatur melalui kebijakan pemerintah pada tahap berikutnya. KPM merupakan keluarga berbasis data pemerintah, yang ditetapkan sebagai penerima manfaat Program BPNT (Kemensos, 2019:7, 9). Program ini berlandaskan pada asas efisiensi dan peningkatan kontribusi keuangan inklusif.

Asas efisiensi, tepatnya efisiensi berkeadilan terumuskan original intensnya pada Pasal 33 Ayat (4) Undang-Undang Dasar 1945. Formulasi yuridisnya : “(4) Perekonomian nasional diselenggarakan berdasar atas demokrasi ekonomi dengan prinsip kebersamaan, efisiensi berkeadilan, berkelanjutan, berwawasan 
lingkungan, kemandirian, serta dengan menjaga keseimbangan kemajuan dan kesatuan ekonomi nasional."

Penafsiran Mahkamah Konstitusi terhadap pasal tersebut tercermin dari putusan Mahkamah Konstitusi Nomor 001-021-022/PUU-I/2003 mengenai pengujian hukum terhadap Undang-Undang Ketenagalistrikan 2002 (Anugroho, Lestarini, \& Hayati, 2017:183-210). Hasil putusan itu, menetapkan bahwa pesan utama diksi efisiensi berkeadilan terletak pada rumusan perekonomian nasional basis penyelenggaraannya, menggunakan sumber daya serendah mungkin atau seminimal mungkin guna mencapai kemakmuran bersama, dan sebesar-besarnya atau semaksimal mungkin dapat dinikmati secara merata oleh segenap rakyat Indonesia. Dengan demikian titik tekan batasan efisiensi berkeadilan terletak pada penggunaan sumber daya serendah mungkin, dalam upaya meraih kemakmuran semaksimal mungkin yang diperuntukan seluruh rakyat berbasis pemerataan. Selain itu prinsip efisiensi berkeadilan tersurat keniscayaan berkompetisi sehat, karena hukum manajemen menerangkan bahwa kualitas output ditentukan juga oleh adanya persaingan yang sehat dalam berlomba melayani kepentingan pelanggan (service excellence). Sementara itu makna pelanggan dalam konteks berbangsa dan bernegara adalah seluruh rakyat.

Sementara itu, kebijakan ekonomi inklusif merupakan produk hukum turunan dari UUD 1945 berupa Perpres No 82 Tahun 2016 tentang Strategi Nasional Keuangan Inklusif. Mengacu kepada tertib hukum peraturan perundang-undangan, maka Perpres No 82 Tahun 2016 harus tegak lurus kepada norma yang lebih tinggi yaitu asas efisiensi berkeadilan yang tercantum dalam UUD 1945. Batasan pengertian keuangan inklusif merupakan upaya peningkatan kesejahteraan masyarakat, sesuai dengan kebutuhan dan kemampuan, melalui layanan keuangan formal yang bercirikan ketepatan waktu, lancar, dan aman serta berbiaya murah (terjangkau) sebagai ukuran kualitasnya (Perpres No 82, 2016 : 2). Pengertian ini, memiliki konsekuensi hukum bahwa hanya dalam kondisi mencapai kesejahteraan masyarakat, kebijakan pemerintah membingkai setiap program kebijakan yang terkait domain publik. Termasuk didalamnya adalah program bantuan pangan non (BPNT). 
Maka secara prinsip dasar BPNT berlandaskan pada dua pilar kokoh bernama efisiensi berkeadilan dan keuangan inklusif. Konstruksi perumusan kebijakan tersebut wajar karena niat awal pemerintah manapun selalu berbasis konstitusional yaitu menjadikan tujuan Negara Republik Indonesia di dalam pembukaan UUD menjadi cita hukum penyelenggara Negara.

Harapan yang baik sesuai dengan arah kebijakan BPNT merupakan dambaan setiap pengambil keputusan yaitu pemerintah.

Filsafat hukum membantu kita dalam mengevaluasi produk hukum dan kebijakan pemerintah. Hans Kelsen adalah sebagian pemikir atau sarjana di bidang hukum yang memiliki pandangan tentang teori atau konsep hukum murni yang dikenal dengan The Pure Theory of Law (Kelsen, 1967). Pendekatan ini penting karena fakta hukum berupa kebijakan BPNT, perlu dilihat dari lensa hukum murni. Meskipun pada ranah implementasi beririsan dengan sosiologi hukum dan dimensi lainnya.

Faktanya, terdapat praktek monopoli pengadaan beras dan telur dalam BPNT, yang terjadi pada penerapan program di tingkat hilir. Yaitu ketika supplier beras dan telur ternyata hanya dipasok oleh satu pemasok tunggal, melalui proses transaksi dengan pihak regulator (Dinas Sosial). Lebih jelasnya problematika penyaluran BPNT, masih bernuansa kolusi dengan pihak pemasok kebutuhan beras dan telur dalam program BPNT itu. Fakta hukum itu, sebagaimana terumuskan dalam proses penyelidikan dugaan tindak pidana korupsi penyalahgunaan program Bantuan Pangan Non Tunai (BPNT) di Kabupaten Rembang Jawa Tengah (SP.Lidik/353/X/2019/Reskrimsus, tanggal 18 Oktober 2019). Sehingga permasalahan awal dalam artikel ini berangkat dari benturan kepentingan antara domain tata kelola (pemerintah) dan tata usaha (pengusaha atau pemasok). Irisan antara dua kepentingan tersebut, membawa konsekuensi penyimpangan dalam program BPNT.

Evaluasi terhadap fakta tersebut, membutuhkan seperangkat perspektif filsafat hukum. Mengapa dapat terjadi distorsi asas efisiensi berkeadilan dalam penyaluran BPNT. Bagaimana filsafat hukum murni menjawab pertanyaan tersebut. 
Artikel ini bertujuan menjawab pertanyaan rumusan masalah sebagai berikut bagaimanakah filosofis efisiensi berkeadilan dalam kebijakan bantuan pangan non tunai?

Setiap penulisan karya ilmiah meniscayakan metode penulisan yang tepat. Pemilihan metode penulisan ilmiah penting karena sangat diperlukan dan sebagai pedoman dalam analisis terhadap data penelitian. Salah satu ciri dari karya ilmiah di bidang hukum adalah mengadung kesesuaian dan mengandung kebenaran yang dapat dipertanggungjawabkan (Soemitro, 1988:10). Cara yang digunakan dalam kajian data sampai dengan merumuskan solusi terhadap masalah yang diangkat menggunakan yuridis normatif dalam arti yang luas dan sempit (Sudarto, 1981, hal. 13). Jika yang dikaji tidak hanya hubungannya dengan perangkat norma belaka, melainkan yang terutama memandang pentingnya efek sosial dari pembentukan norma-norma (hukum) sedemikian rupa sehingga justru yang dilihat utama adalah latar belakang kemasyarakatannya, maka metode ini disebut metode yuridis normatif dalam pengertian luas. Sementara itu jika penulis membahas mengenai formulasi yuridis dalam ketentuan tentang program BPNT pendekatan yang digunakan adalah yuridis normatif dalam arti sempit. Sehingga keseluruhan dari artikel ini terkait dengan metode yuridis normatif, dalam pengertian luas maupun sempit.

\section{Pembahasan}

Teori Hukum Murni, memberikan penjelasan untuk menerangkan bahwa ilmu hukum merupakan suatu disiplin ilmu yang memiliki derajat perbedaan dengan ilmu lain. Kontraversial pemahaman tentang teori ini dapat terurai sebagai berikut (Asshiddiqie \& Safa'at, 2006:viii):

"Teori Hans Kelsen tentang hukum hanya dipahami oleh sebagian kalangan secara utuh. Hal ini berakibat, seringnya kesalahpahaman dalam mencerna teorinya. Contohnya tema tentang keadilan. Pada satu sisi, pakar hukum kurang setuju pandangan Hans Kelsen berdasarkan argumentasi bahwa teorinya berlaku pemisahan hukum dengan keadilan. Sementara itu, pada sisi yang lain lagi ada ahli hukum yang salah memahami bahkan menerima bahwa hukum tidak berhubungan dengan keadilan. Pandangan Kelsen menerangkan bahwa hukum dan keadilan merupakan dua hal yang berbeda. 
Peletakan kajian hukum berbasis normatif semestinya dipisahkan dari keadilan yang berkarakter ideologis. Hal ini jauh dari pengertian bahwa tiada hubungan antara keadilan dan hukum. Peran keadilan terletak pada proses making of law dan penegakan hukum di pengadilan."

Struktur logika dalam pemahaman tentang teori hukum murni menjadi pola baru para filosof hukum. Sistematika logika formal tersebut, berkembang sejak lama dan merupakan karakter utama filsafat Neo-Kantian selanjutnya bertransformasi yang dikenal sebagai aliran strukturalisme (Jeliae, 1998:147).

Jika filsafat kita ukur atau batasi pengertiannya sebagai pengetahuan dan penyelidikan dengan akal budi mengenai hakikat segala yang ada, sebabnya, asalnya, hukumnya (KBBI, 2008:414). Maka Teori Hukum Murni dari Hans Kelsen adalah timbangan dalam memaknai keadilan dipandang dari ilmu hukum. Bukan makna keadilan yang tersembunyi di dalamnya tentang justifikasi ideologis bahkan yang transcendental (mutlak, absolut). Hans Kelsen menawarkan cara pandang terhadap ilmu hukum hasil dari (Rice, n.d., hal. 1-2):

"Kelsen mendalilkan teori hukumnya berbasis pada aliran relativisme filosofis (philosophical relativism) yang menyetujui doktrin empiris, yaitu pandangan tentang realitas, yang menerangkan bahwa realitas ada dalam ranah pengetahuan pemikiran manusia dan realitas dipandang sebagai obyek pengetahuan. Realitas dipandang sebagai yang absolut. Selain itu, realitas dipahami berada di luar pengalaman manusia. Realitas ini di luar pengetahuan manusia yang tidak mampu diakses dan diketahui. Kelsen berkeyakinan jika absolutisme filosofis (philosophical absolutism) berakhir menjadi absolutism politik, demikian pula dengan relativisme filosofis yang berhenti pada relativisme politik, atau demokrasi. Disebabkan oleh hukum bersifat bebas nilai, (baik dari nilai benar atau salah atau keadilan absolut), dengan demikian hukum dapat diukur melalui terwujudnya kesetaraan individu dalam pemenuhan kepentingannya dan diartikulasikan dalam rumusan sebagai kehendak mayoritas. Sebagian besar aliran positivism berpandangan bahwa rasio manusia tidak mampu mengetahui sesuatu itu benar atau salah."

Dalam ranah kebijakan publik (baca: hukum sebagai basic idea nya), ada dua aliran filsafat kebijakan yang sampai sekarang digunakan oleh pemerintahan di dunia yaitu :

1. Paradigma Utilitarianisme, Jerome Bentham sebagai pionernya dengan tesis pada teorinya bahwa kebahagian disebut adil itu jika sebagian besar masyarakat mendapatkannya (mayoritas mendapatkannya). Ide awalnya, 
setiap manusia setara dalam kebutuhannya. Pada historis filsafat ini, menerangkan bahwa ide kesetaraan pada masanya adalah revolusioner karena kebahagian saat itu (Abad ke 17) hanya ditentukan oleh aristrokasi kerajaan maupun keagamaan (gereja).

2. Paradigma Libertarianisme. Ide dasarnya memandang bahagia dilihat dari kebahagiaan individu. Setiap orang mempunyai preferensi tentang kebahagiannya sendiri.

Paradigma utilitarianisme merupakan cara pandang dasariah ekonomi yang menyelusup ke dalam pemikiran hukum. Kerangka utama pemikiran paradigma ini, terletak pada tujuan dan bagaimana mengevaluasi hukum. Hukum bertujuan sebagai alat mensejahterakan sebagian besar masyarakat, sedangkan evaluasi hukum menganalisis dampak bagi penerapan hukum di masyarakat. Konsekuensi logis dari fungsi hukum tersebut, membawa pandangan baru bahwa ketentuan (isi) yang terkandung di dalam hukum mestinya berupa pengaturan tentang penciptaan kesejahteraan bagi sebesar-besarnya kesejahteraan negara dan masyarakat (Rondonuwu, 2014:75). Kepentingan umum menjadi kata kunci ketika melihat operasionalisasi ide utilitarian dalam kebijakan berbingkai hukum. Diksi dalam batang tubuh, yang mengatur tentang perekonomian, UUD 1945 merumuskan sebesar-besarnya untuk kemakmuran rakyat.

Mahkamah Konstitusi (MK) menafsirkan "efisiensi berkeadilan” yang terformulasi yuridis pada Pasal 33 ayat (4) yaitu pada hakekatnya berisi tentang upaya membangun perekonomian Indonesia, secara bergotong-royong berbasis pada demokrasi ekonomi (Anugroho et al., 2017:198). Peran negara sebagai suprastruktur yang menguasai cabang-cabang produksi yang menguasai hajat hidup orang banyak. Peran tersebut dioperasionalkan lewat pengaturan, pengurusan, pengawasan dan pengelolaan yang efisien dan efektif. Sebagai penekanan tata kelola Negara tersebut, dapat dikatakan bahwa kerugian pada kegiatan produksi di atas, masih dapat diasumsikan efisien, selama kerugian itu disubsidi dan tanpa memboroskan sumber daya sosial. Norma ini berlaku pada 
fungsi Negara, dalam pencapaian kemakmuran semaksimal mungkin bagi seluruh rakyat Indonesia.

Beranjak dari argumentasi sebelumnya, maka bingkai kebijakan program pemerintah yang senafas dengan efisiensi berkeadilan, membawa konsekuensi bahwa kebijakan boleh jadi timbul subsidi Negara, dengan batasan bahwa tidak terjadi pemborosan sumber daya sosial. Artinya kepentingan masyarakat (kemakmuran sebesar-besarnya bagi seluruh rakyat) menjadi patokan utama dalam kebijakan pemerintah. Tersirat bahwa kebijakan BPNT salah satunya juga termasuk kualifikasi dari filsafat hukum utilitarianisme.

Bukti bahwa pendekatan utilitarianisme mengemuka pada kebijakan BPNT, adalah terumuskannya adanya diksi "kemakmuran sebesar-besarnya bagi kepentingan rakyat". Jika dibahasakan dalam paham utilitarianisme maka diksi tersebut berbunyi kebahagiaan (makmur) bagi sebagian besar masyarakat (rakyat). Berbasis ide dasar dalam paham utilitarianisme tersebut jelas bahwa kebijakan BPNT tegak lurus dengan grundnorm (Norma Dasar) dalam pembukaan UUD 1945, memajukan kesejahteraan umum yang menjadi tujuan Negara Republik Indonesia.

Norma Hukum Kebijakan Program BPNT, memberikan beberapa batasan atau ukuran implementasi program. Pertama, ruang lingkup BPNT merupakan kebijakan sosial berujud pangan yang didistribusikan melalui uang elektronik, kepada KPM dalam jangka waktu setiap bulan, dan diperuntukan oleh KPM guna memperoleh bahan pangan di e-Warong (Pedoman Umum BPNT, 2019 :7). Sedangkan pengertian KPM merupakan keluarga yang ditetapkan berbasis data pemerintah, sebagai penerima manfaat Program BPNT. Sementara itu, yang dimaksud dengan e-Warong merupakan sebutan bagi Elektronik Warung Gotong Royong. Fungsinya adalah agen dari bank (Himbara), sebagai pedagang dan/atau pihak-pihak yang menjalin kerja sama dengan Bank Penyalur. Fungsi lainnya sebagai toko atau warung penyedia bahan pangan yang akan dibeli oleh KPM. Bentuknya dapat berupa beraneka ragam meliputi : usaha mikro, usaha kecil, serta dalam bentuk koperasi. Selain itu dapat pula pasar tradisional, sebuah warung, bentuk usaha toko kelontong, e-Warong KUBE (Kelompok 
Usaha Bersama), dapat pula berbentuk Warung Desa, atau sejenis Rumah Pangan Kita (RPK), kemudian berbagai jenis agen seperti : Agen Laku Pandai, Agen Layanan Keuangan Digital (LKD) yang kesemuanya, inti usaha memiliki bisnis utama menyediakan dan memperdagangkan bahan kebutuhan pangan, serta usaha retail lainnya (Pedoman Umum BPNT, 2019:8).

Ide dasar atau basic idea dari program BPNT ini secara normatif dirumuskan sebagai berikut :

a. penyaluran bantuan sosial kepada masyarakat berbasis kepada prinsip efisien dengan ukuran ketepatan sasaran, jumlah, waktu, kualitas, dan administrasi;

b. atas dasar penyaluran bantuan sosial yang efisien, diharapkan mendukung peningkatan manfaat bagi KPM serta mendorong peningkatan keuangan inklusif.

Dari rumusan filosofis dalam peraturan perundangan tersebut tersirat bahwa ide efisiensi penyaluran bantuan sosial diharapkan mampu tercapai 6T yaitu tepat sasaran, jumlah, waktu, kualitas, harga dan administrasi. Selain itu, gagasan efisiensi penyaluran bantuan sosial diharapkan pula meningkatkan manfaat bagi penerima bantuan dan berkontribusi terhadap keuangan inklusif. Adapun yang dimaksud dengan keuangan inklusif merupakan gagasan kebijakan yang meliputi kondisi setiap anggota masyarakat memiliki jalur kepada berbagai layanan sistem keuangan formal berdasarkan kualitas yang bercirikan tepat waktu, lancar, dan aman berbiaya yang dapat dijangkau masyarakat. Bersesuaian dengan kebutuhan dan kemampuan dalam rangka meningkatkan kesejahteraan masyarakat (Perpres No 82, $2016: 2$ ).

Asas efisiensi menjadi landasan utama legal substance Kebijakan BPNT. Inti asas ini adalah dengan input (sumber daya) seminimal mungkin dapat dicapai output (manfaat) semaksimal mungkin. Demi kesejahteraan masyarakat. Beberapa aturan atau norma hukum yang menjadi landasan program BPNT, pada prinsipnya menggunakan pilihan pidana dan non pidana sebagai bentuk pertanggungjawaban para stake holder yang terlibat implementasi program BPNT. 
Skema Kebijakan BPNT jika kita sederhanakan cara kerjanya terlihat sebagai berikut :

1. Terdapat lima stake holder yang berkepentingan dalam program ini. Yaitu KPM, masyarakat, E-Warong, Bank dan Pemerintah baik Pusat maupun Daerah.

2. Masing-masing stake holder dapat diuraikan lebih lanjut mengenai fungsi kerjanya yang meliputi aspek peran dan tujuan. Pertama, KPM berperan sebagai penerima BPNT dengan tujuan menerima bahan pangan non-tunai sesuai dengan 6T yaitu Tepat Sasaran, Tepat Jumlah, Tepat Kualitas, Tepat Harga, Tepat Waktu dan Tepat Administrasi. Kedua, Masyarakat berperan sebagai Pengusaha Eceran Rakyat dengan tujuan memperoleh pelanggan dan peningkatan penghasilan. Ketiga, E-Warong berperan sebagai penyedia BPNT dan kepanjangan tangan Bank dengan tujuan membeli pasokan bahan pangan BPNT sesuai dengan 6T. Keempat, Bank berperan sebagai penyalur dana BPNT dengan tujuan melayani penyaluran bantuan berupa jasa keuangan kepada KPM dan usaha retail masyarakat. Kelima, Pemerintah berperan sebagai pengawas program BPNT dengan tujuan mengawal program BPNT sesuai dengan petunjuk pelaksanaan dan petunjuk teknis BPNT.

Sebagai alternatif program pemerintah, maka BPNT sebagaimana dalam awal pembahasan dapat ditafsirkan bahwa paradigma utilititarian, mendominasi dasar pemikirannya. Selanjutnya bagaimana dengan pandangan Hans Kelsen dalam memposisikan keadilan dalam bingkai hukum kebijakan BPNT.

Dasar dalil Hans Kelsen dalam Teori Hukum Murni adalah:

1. Keterangan yang menjelaskan karakter hukum bersifat baik serta selaras dengan moralitas, dibenarkan oleh teori ini. Sementara itu dalam perspektif hukum merupakan bagian dari moral dan semua hukum merupakan bagian atau derajat tertentu dari moral, tidak disepakati dalam teori ini. Argumentasinya, jika menyatakan hukum merupakan aspek moralitas maka 
hal ini sama dengan berpendapat bahwa hukum harus sesuai moralitas (Kelsen, 1992:15).

2. Dualisme berupa hukum positif dan hukum alam, merupakan karakteristik utama doktrin hukum alam. Eksistensi kesempurnaan hukum alam lebih tinggi dibandingkan dengan hukum positif yang tidak sempurna. Kebenaran hukum positif bernilai benar jika bersesuaian kepada hukum alam. Dua hal itu, yakni hukum alam dan hukum positif, mengakibatkan terwujudnya dualisme baru berupa realitas dan ide Platonik. Plato berteori dalam filsafatnya, idea tentang dua wilayah dunia (sphere) yaitu dunia nyata atau realitas. Sebagai pasangannya adalah dunia yang tidak kelihatan, yakni dunia gagasan (ide). Nampaknya Plato lebih jelas menerangkan bahwa suatu realitas hanyalah tiruan ketidaksempurnaan dari dunia ide. Konsep tersebut diterangkan sebagai dualisme nature dan supernature. (Kelsen, 1961:12)

3. Hukum alam yang bersifat metafisik, berhubungan dengan konsep transendental hukum. Secara maknawi konsep "transenden" adalah berarti di luar batas wilayah yang terkandung dalam pengalaman yang dialami oleh manusia. Sehingga pandangan tersebut, jauh berbeda dengan penjelasan transenden ala aliran filasafat yang dikonstruksi oleh Kant (yang didalilkan oleh Kelsen), dimana meletakan aktivitas penelitian yang berhubungan dengan kemungkinan dari pengalaman (Kelsen, 1992:21).

4. Dualisme ini menghasilkan dua pilihan, yaitu sifat optimistic-conservatif atau pessimistic-revolutionary yang merujuk kepada ide atas pertanyaan adakah keselarasan atau ketidakselarasan pada wilayah dualisme realitas empiris dengan ide transendental. Metafisik tersebut bertujuan menerangkan realitas sebagai yang irrasional, sementara di sisi lainnya menolak ataupun menerimanya berdasarkan emosional semata. Berbasis kepada premis pertama yakni jika wilayah ide merupakan pengetahuan yang diketahui. Selanjutnya premis kedua dirumuskan : atau bila terdapat keadilan yang dipercaya obyektifitasnya. Maka tiada urgensi adanya hukum yang berlaku saat ini (positif) dan sebuah wadah bernama Negara. 
Disebabkan oleh tiadanya lagi kebutuhan untuk membahagiakan manusia (Kelsen, 1961:12-13).

5. Keadilan adalah sesuatu diluar rasio karena itu bagaimanapun pentingnya bagi tindakan manusia, tetap bukan subyek pengetahuan. Bagi pengetahuan rasional yang ada, fakta di dalam masyarakat yang terjadi adalah aspek kepentingan dan konflik kepentingan. Alternatif pemecahan masalahnya adalah merumuskan tata aturan yang memenuhi kepentingan tertentu, dengan jalan mengesampingkan kepentingan lainnya. Atau ditempuh langkah kompromi sedemikian sehingga terjadi harmoni antar kepentingan. Kedua pilihan itu, pengetahuan rasional tidak mampu menentukan mana yang dianggap adil. Hukum positif, berupa undang-undang, yang ditentukan secara obyektif yang menjadi bahan pengetahuan terhadap fakta masyarakat tersebut. Tata aturan tersebut, sebagai obyek ilmu, dan bukan merupakan hukum dalam arti metafisik. Keterangan ini menjelaskan hukum apa adanya, tanpa merujuk kepada diksi adil ataupun tidak adil. Kerangka penjelasan dalam prinsip nya, menerangkan dalam pencarian hukum yang bersifat nyata dan sangat mungkin diterapkan, bukan hukum yang hanya bersifat benar (Kelsen, 1961:13).

6. Berbasis pengalaman selama ini, hanya fungsi tata hukum yang mampu berkompromi antar kepentingan yang berlawanan dan meminimalkan adanya gesekan. Operasional tata hukum itulah yang dapat menyelamatkan perdamaian sosial yang sedang menghadapi problematika. Meskipun ada perbedaan antara ide keadilan dan gagasan perdamaian, akan tetapi keduanya memiliki kecenderungan nyata untuk diidentikkan, atau sekurangkurangnya sebagai pengganti ide perdamaian, disubstitusi oleh ide keadilan (Kelsen, 1961:14).

7. Keadilan bermakna legalitas, jika suatu norma (aturan) diterapkan pada semua kasus yang menurut rumusan aturan legalnya harus diaplikasikan, maka disebut adil. Berlawanan dengan silogisme itu, maka bila suatu norma diimplementasikan pada satu kasus saja tanpa diterapkan dikasus lainnya yang berbobot sama maka disebut tidak adil (Kelsen, 1992:16 dan 25). 
8. Keadilan pada ranah legalitas adalah suatu kualitas yang tidak berhubungan dengan isi tata aturan positif yang berlaku, tetapi dengan pelaksanaan atau penerapannya. Sudut pandang legalitas, merumuskan bahwa perbuatan individu dinilai adil atau tidak adil dapat bermakna legal atau ilegal, yaitu tindakan tersebut sesuai atau tidak sesuai dengan norma hukum yang valid dalam kandungan tata hukum positif. Optik yang terdapat pada hakekat legalitas itulah, keadilan dapat digolongkan ke dalam tubuh ilmu hukum (Kelsen, 1961:14).

Menurut pandangan penulis, Teori Hukum Murni merupakan metode filsafat hukum, yang di dalamnya memurnikan dari dua pendekatan yaitu berbeda dengan hukum alam dan yang kedua asal usul hukum bukan pada pandangan ideologi politik.

Kegunaan dari metode dari Hans Kelsen ini adalah bagaimana kita menguji basic idea dari pelaksanaan kebijakan BPNT. Meminjam dalil dari Hans Kelsen yang menerangkan bahwa ukuran atau batasan keadilan pada konteks legalitas merupakan kualitas yang bertanggungjawab terhadap operasional keadilan dalam pelaksanaannya. Bukan kaitannya dengan isi tata aturan positif yang berlaku. Maka penulis bermaksud menguji implementasi atau penerapan atau pelaksanaan kebijakan BPNT dari timbangan atau ukuran pelaksanaannya.

Hasil pengujian antara basic idea program BPNT melalui neraca timbangan metode filsafat hukum murninya Hans Kelsen mendapatkan bukti bahwa :

1. Landasan asas "Efisiensi Berkeadilan" dalam Kebijakan BPNT, mengalami penyimpangan pelaksanaan ketika terjadi fakta monopoli suplai pasokan bahan pangan dari pemasok ke E-Warong. Sebagaimana terhimpun dalam pengumpulan bukti dan keterangan tersangka kasus dugaan tindak pidana korupsi penyalahgunaan program Bantuan Pangan Non Tunai di Kabupaten Rembang Jawa Tengah (lihat kasus a quo sebelumnya).

2. Efisiensi dalam arti makna ekonomi kapitalis (hanya segelintir orang yang bermodal, dan memiliki kekuasaan mempengaruhi rantai pasokan) sebagaimana dikuatirkan dalam kebijakan legislasi Amandemen UUD 1945 
terjadi. Yaitu fakta hukum yang menjelaskan bahwa monopoli jalur pasokan bahan pangan itu memang empiris adanya.

3. Pendulum asas efisiensi lebih dominan daripada diksi "berkeadilan" sehingga menghasilkan ketimpangan atau asimetris kebijakan hukum awalnya dengan implementasi di wilayah publik (masyarakat).

\section{Penutup}

\section{A. Kesimpulan}

Program BPNT berasaskan efisiensi berkeadilan, dalam perspektif filsafat hukum bersumber pada paradigm utilitarianisme yang berteori bahwa kebahagian bersifat adil manakala dinikmati oleh mayoritas masyarakat. Dalil dalam Filsafat Hukum Murninya Hans Kelsen, yang menerangkan bahwa ukuran atau batasan keadilan pada konteks legalitas merupakan kualitas yang bertanggungjawab terhadap operasional keadilan dalam pelaksanaannya. Bukan kaitannya dengan isi tata aturan positif yang berlaku. Maka kebijakan program BPNT, asas "Efisiensi Berkeadilan" mengalami penyimpangan pelaksanaan ketika terjadi fakta monopoli suplai pasokan bahan pangan dari pemasok ke EWarong, pendulum efisiensi hanya dominan ke arah ekonomi yang dikuasai segelintir orang yang berkuasa. Keadilan demi kemakmuran sebesar-besarnya bagi rakyat masih jauh dari ideal.

\section{B. Saran}

Guna meminimalkan penyimpangan dari program BPNT, perlu diajukan alternatif kebijakan berupa bantuan langsung tunai. Mengingat hampir setiap kebijakan yang berkaitan dengan barang selalu muncul faktor kriminogen koruptif. Sebagaimana prediksi Robert Klitgaard dalam tesisnya yang menerangkan bahwa Korupsi dapat terjadi pada kondisi monopoli, adanya diskresi pelaksana dan minimnya akuntabilitas sebuah program. 


\section{Daftar Pustaka}

Anugroho, A., Lestarini, R., \& Hayati, T. (2017). Analisis Yuridis terhadap Asas Efisiensi Berkeadilan Berdasarkan Pasal 33 ayat (4) UUD 1945 dalam Peraturan Perundang-undangan di bidang Ketenagalistrikan. Jurnal Hukum \& Pembangunan, 47(2). https://doi.org/10.21143/ jhp.vol47.no2.1451

Asshiddiqie, J., \& Safa'at, M. A. (2006). Teori Hans Kelsen Tentang Hukum. Jakarta: Sekretariat Jenderal dan Kepaniteraan Mahkamah Konstitusi RI.

Jeliae, Z. (1998). A Note on Adolf Merkl's Theory of Administrative Law. Journal Facta Universitatis, Series: Law and Politics, 1(2). Diambil dari http://facta.junis.ni.ac.rs/lap/lap98/lap98-02.pdf

Kelsen, H. (1961). General Theory of Law and State. New York: Russell \& Russell.

Kelsen, H. (1967). Pure Theory of Law. London: University of California Press.

Kelsen, H. (1992). Introduction to The Problems of Legal Theory. Oxford: Clarendon Press.

Pusat Bahasa Departemen Pendidikan Nasional. (2008). Kamus besar bahasa Indonesia. Jakarta: Gramedia Pustaka Utama.

Republik Indonesia. Peraturan Presiden Republik Indonesia No. 82 Tahun 2016 Tentang Strategi Nasional Keuangan Inklusif.

Republik Indonesia. Surat Perintah Penyelidikan Nomor: SP.Lidik/353/X/2019/Reskrimsus, tanggal 18 Oktober 2019.

Republik Indonesia. Undang-Undang Dasar Negara Republik Indonesia 1945.

Rice, C. E. (n.d.). The Role of Legal Ethics and Jurisprudence in National Building.

Rondonuwu, D. E. (2014). Ilmu Hukum Dalam Perspektif Ilmu Pengetahuan Modern. Lex Crimen, III(2). Diambil dari https://ejournal.unsrat.ac.id/index.php/lexcrimen/article/view/4546

Soemitro, R. H. (1988). Metodologi Penetian Hukum dan Jurumetri. Jakarta: Ghalia Indonesia.

Sudarto. (1981). Masalah Penghukuman dan Gagasan Pemasyarakatan, Kapita 
Selekta Hukum Pidana. Bandung: Alumni.

Tim Pengendali Pelaksanaan Penyaluran Bantunan Sosial Secara Non Tunai. (2019). Pedoman Umum Bantuan Pangan Non Tunai. Jakarta: Kementrian Koordinator Bidang Pembangunan Manusia dan Kebudayaan Republik Indonesia. 